\title{
Impacts of Cycled Dietary Protein Ratios on the Growth Performance and Somatic Indices of Meagre (Argyrosomus regius)
}

\author{
Derya Güroy ${ }^{1}$ (D), Onur Karadal ${ }^{2}$ (D)
}

Cite this article as: Guroy, D., Karadal, O. (2019). Impacts of cycled dietary protein ratios on the growth performance and somatic indices of meagre (Argyrosomus regius). Aquatic Sciences and Engineering, 34(2), 61-66.

ORCID IDs of the authors: D.G. 0000-0002-8254-1403; O.K. 0000-0002-6241-5039

'Department of Aquaculture, Armutlu Vocational School, Yalova University, 77500, Armutlu, Yalova, Turkey

${ }^{2}$ Department of Aquaculture, Faculty of Fisheries, İzmir Kâtip Çelebi University, 35620, Çiğli, İzmir, Turkey

Submitted:

16.03.2019

Revision Requested 22.04.2019

Last Revision Received 25.04.2019

Accepted:

25.04.2019

Online published:

28.06.2019

Correspondence:

Derya Güroy

E-mail:

dguroy@yahoo.com

Onur Karadal

E-mail:

onur.karadal@ikc.edu.tr

(C) Copyright 2019 by Aquatic

Sciences and Engineering

Available online at

https://dergipark.org.tr/ase

\begin{abstract}
Protein is both an essential and a costly nutrient in aquafeeds. In this study, the effects of different cyclic protein ratios on growth performance, biological indices, and profitability of meagre (Argyrosomus regius) were investigated. Diets which included 48, 44, and 40\% protein ratios were prepared, and the experimental groups were designed by cyclical periods of $48 \%$ for 12 weeks (P48, control), 40\% for 6 weeks $+48 \%$ for 6 weeks (P40/48), and 44\% for 6 weeks $+48 \%$ for 6 weeks (P44/48). The study was carried out with three replicates for 12 weeks in nine $450 \mathrm{~L}$ fiberglass tanks connected to a recirculating marine water system. Meagre with an average weight of $49.93 \pm 0.35$ $g$ were kept with 10 fish per tank. At the end of the study, the best weight gain was observed in the P48 group compared to the other treatments $(P<0.05)$. However, no statistical differences were found between the specific growth rates and feed conversion ratios of the experimental groups ( $P>0.05)$. In addition, both condition factor and viscerosomatic index were higher in $\mathrm{P} 44 / 48$ and $\mathrm{P} 40 / 48$, respectively $(\mathrm{P}<0.05)$. In conclusion, aquafeeds with a protein content of $48 \%$ can be circulated for short periods as part of $40 \%$ protein diets.
\end{abstract}

Keywords: Marine aquaculture, fish nutrition, cycled feeding, profitability, Argyrosomus regius

\section{INTRODUCTION}

Protein is a dietary nutrient that directly affects growth, weight gain, and biological parameters in fish. Protein requirements of fish are influenced by several biotic and abiotic factors, including species, size, age, physiological situation, diet quality, protein to energy ratio, temperature, salinity, etc. (Tacon and Cowey, 1985; NRC, 2011). Determination of daily protein amounts per animal is particularly necessary in culture conditions (Kureshy and Davis, 2002). Dietary protein deficiency prevents fish from reaching their maximum growth values and excessive protein in the feed is not suitable both economically and environmentally (Lovell, 1989). Nevertheless, protein is considered as a limiting factor in aquafeeds, because of its high costs (Gatlin III et al., 2007). For this purpose, researchers have focused on decreasing protein ratios (especially fish meal proteins) in aquafeeds using various methods such as increasing the amount of plant-based raw materials (soybean meal, corn meal, etc.), using alternative animal-based protein sources (squid meal, krill meal, etc.), and applying different feeding strategies (feeding level, feeding frequency, feeding rate, etc.). However, some of these methods are not suitable for certain fish species. For example, carnivorous fish need a diet including high amounts of animal-based proteins and increasing the level of plant-based ingredients in their aquafeed depresses the growth of fish (Hartviksen et al., 2014). The best method for these species is to apply specific feeding regimes, including cycled nutrition combined with diets containing different protein levels.

Feeding is an important operation in aquaculture because it accounts for the largest share of 
expenses in the production process. This share might be balanced with the application of proper feeding regime (Güroy et al., 2017). Feeding management depends on different factors, including species, size of fish, physical conditions of facilities, farmer/staff experience. Regular feeding regimes should specify an integrated schedule of these factors. Regulating the optimum feeding schedule for cultured species may improve the growth performance, survival rate, and feed utilization by decreasing feed wastage (Jiwyam, 2010; Okorie et al., 2013). One of the basic applications of a proper feeding regime is the cycling of aquafeeds or feed ingredients. Some compensatory growth studies have been carried out on different commercial fish species, including rainbow trout (Oncorhynchus mykiss), gilthead sea bream (Sparus aurata), and European sea bass (Dicentrarchus labrax) (Quinton and Blake, 1990; Eroldoğan et al., 2008; Türkmen et al., 2012) which focus on feeding the fish with restricted/cycled periods or starvation. These kinds of studies aimed to minimize consumption of feed by decreasing or limiting and cycling the portions and thus, improving profitability. In other feeding regime studies, the ratio of important nutrients such as protein in the diet was reduced instead of the feeding rate. For example, Gaylord and Gatlin III (2001) carried out a study with diets which included different protein and energy ratios on channel catfish (Ictalurus punctatus).

Meagre (Argyrosomus regius) is a high potential marine fish which is popular in Mediterranean aquaculture due to its valu- able meat quality and flavour (Vallés and Estévez, 2013; Güroy et al., 2017). This species has been readily accepted for culturing by farmers because of its exceptional natural features in culture conditions such as its high growth performance (Monfort, 2010; Ribeiro et al., 2013). Also, meagre shows advanced survival rates, optimum feed conversion ratio, and a more rapid growth rate than gilthead sea bream ( $S$. aurata) and sea bass (D. labrax) in aquaculture conditions (Barata et al., 2016; Emre et al., 2016). The market share of meagre is increasing day by day. Determining the specific feed needs and feeding regimes of meagre is important for the expansion of market share.

The aim of this present study was to investigate the influence of diets composed of different protein ratios by giving cyclical portions to meagre (Argyrosomus regius). Thus, it is predicted that using a combination of cyclical feeds alternating low and high protein content may reduce feed costs if it leads to positive effects on growth performance.

\section{MATERIALS AND METHODS}

\section{Experimental design and diets}

Three protein levels were determined (40,44, and 48\%) and cycled feeding regimes were applied in this study. The control group (P48) was continuously fed with diets containing $48 \%$ protein during the experiment. P40/48 and P44/48 groups were fed

Table 1. Formulation and proximate composition of the experimental diets

\begin{tabular}{|c|c|c|c|}
\hline Ingredients & P40 & P44 & P48 \\
\hline Fish meal $^{1}$ & 18.80 & 25.00 & 34.00 \\
\hline Corn gluten ${ }^{2}$ & 14.50 & 14.50 & 14.50 \\
\hline Poultry by-product ${ }^{4}$ & 6.00 & 6.00 & 6.00 \\
\hline Feather meal ${ }^{5}$ & 2.40 & 2.40 & 2.40 \\
\hline Wheat gluten ${ }^{6}$ & 2.50 & 2.50 & 2.50 \\
\hline Fish oil9 & 13.65 & 13.65 & 12.15 \\
\hline Vitamin premix ${ }^{10}$ & 0.20 & 0.20 & 0.20 \\
\hline Mineral premix ${ }^{10}$ & 0.15 & 0.15 & 0.15 \\
\hline Choline chloride ${ }^{10}$ & 0.10 & 0.10 & 0.10 \\
\hline Dicalcium phosphate ${ }^{10}$ & 1.14 & 0.68 & 0.00 \\
\hline Crude Ash (\%) & 5.31 & 5.86 & 6.61 \\
\hline Crude Fibre (\%) & 4.04 & 3.75 & 3.10 \\
\hline $\operatorname{NFE}(\%)^{\star}$ & 29.96 & 26.44 & 23.27 \\
\hline \multicolumn{4}{|c|}{ 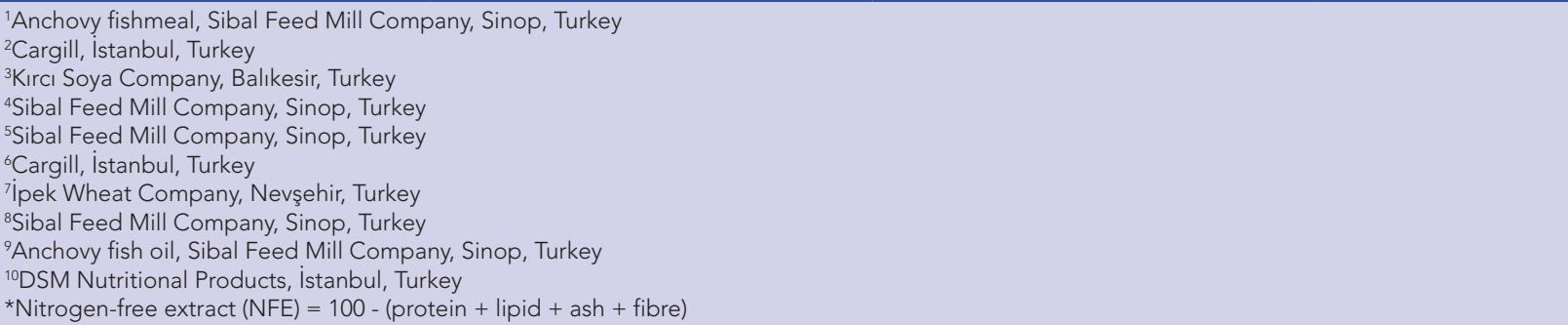 } \\
\hline
\end{tabular}


with diets of $40 \%$ and $44 \%$ protein ratios in the first half (initial 6 weeks) of the experiment, respectively, and then during the second half of the experiment (last 6 weeks), these groups were fed with diets containing $48 \%$ protein. All experimental diets with 40, 44 and $48 \%$ dietary protein were formulated using fish meal, plant ingredients, fish oil and vitamin-mineral mix (Table 1). Dietary ingredients were mixed in a food mixer (Dirmak Food Equipment, IBT-22) with water until a soft slightly moist consistency was achieved. This dough was then cold press extruded (La Monferrina, PTM P6) to produce discs of $4 \mathrm{~mm}$ in diameter. The moist pellets were then fan-dried and stored at $-18{ }^{\circ} \mathrm{C}$ until use.

\section{Rearing system and fish}

Meagre were obtained from a commercial hatchery in Muğla, Turkey and transported to the Marine and Freshwater Fish Unit of Armutlu Vocational School, Yalova University, Turkey. Prior to the feeding trials, the fish were transferred to the $450-\mathrm{L}$ tanks and fed a commercial sea bass diet (45\% protein, 18\% lipid, 2.5\% fibre, $7 \%$ ash; Sürsan Inc., Turkey) for two weeks for acclimation. Nine 450-L circular tanks within a $25000-L$ recirculation seawater system were annexed to a 650-L sand filter, bag filter, and ultraviolet light unit. A partial seawater exchange (15\% total system volume) was performed twice each week. The water flow rate was $5 \mathrm{~L} / \mathrm{min}$ and water quality was monitored daily. Water temperature was maintained at $22.7 \pm 1.01{ }^{\circ} \mathrm{C}$ and dissolved oxygen at $8.12 \pm 0.29 \mathrm{mg} / \mathrm{L}$ (Handy Polaris, Oxy-Guard). Average $\mathrm{pH}$ was recorded at $7.89 \pm 0.17$ (HANNA HI 9125), salinity at 21.2 \pm 0.10 ppt (Atc Refractometer), and ammonia at 0.13 $\pm 0.02 \mathrm{mg} / \mathrm{L}$ (Hach Lange DR 2800). The recirculation system was housed in a climate-controlled unit with controlled photoperiod 12:12 h (light:dark). Meagre (mean body weight $49.93 \pm 0.35 \mathrm{~g}$ ) were randomly distributed over nine fiberglass tanks at a density of 10 fish per tank. Fish were hand-fed to near satiation three times a day (09:00, 13:00, and 17:00) for 84 days. Feed was carefully administered by dropping a few pellets into the tanks until the feeding activity ceased.

\section{Evaluation of growth performance}

Fish were weighed biweekly in bulk after suspending feeding for 1 day. All fish were anesthetized with clove oil (50 mg/L) during the weighing procedure (Barata et al. 2016). Growth parameters, including feed conversion ratio (FCR), specific growth rate (SGR), and survival rate (SR) were calculated using the following equa- tions: FCR $=$ feed intake / weight gain, $S G R=100 \times[(L n$ final fish weight) - (Ln initial fish weight)] / experimental days, $S R=100 x$ (total fish count - dead fish count) / total fish count.

\section{Measurement of somatic indices}

Three fish per tank were randomly selected, individually weighed, and then dissected to obtain the viscera to determine biological parameters. The somatic indices, including condition factor (CF), viscerosomatic index (VSI), hepatosomatic index (HSI), and mesenteric fat index (MFI) were calculated using the following formulae: CF $=100 \times$ (final body weight / fork length $\left.{ }^{3}\right), \mathrm{VSI}=100 \times($ viscera weight / final body weight), HSI $=100 \times$ (liver weight / final body weight), MFI = $100 \times$ (body fat weight / final body weight).

\section{Economic analysis}

Economic analyses in terms of economic conversion ratio (ECR) and economic profit index (EPI) were developed by Sánchez-Lozano et al. (2007). These parameters were determined using the following formulae: $E C R=$ feed conversion ratio $x$ feed price, $\mathrm{EPI}=$ (final body weight $\mathrm{x}$ fish sale price) - (economic conversion ratio $x$ weight gain).

The cost of feed ingredients was as listed by index mundi (IndexMundi, 2018). Meagre sale price was calculated at $4.5 € / \mathrm{kg}$.

\section{Statistical analysis}

The Shapiro-Wilk W test and Levene test were examined to verify normality and homogeneity of variance before further analysis was undertaken. All data was subjected to one-way analysis of variance (ANOVA), after proving the normality and homogeneity of the data. Tukey's multiple range test was used to rank groups when different interaction was found using Statgraphics Centurion XVI (Statpoint Technologies Inc., The Plains, VA) statistical software (Zar, 1999). All data was presented as "mean \pm standard error" of the mean calculated from all replicates. Differences were considered significant at $\mathrm{P}<0.05$.

\section{RESULTS AND DISCUSIONS}

Growth parameters recorded for 6 weeks and 12 weeks of the study are given in Table 2. The mean weight at the $6^{\text {th }}$ week of the P48 group was significantly different to the P44/48 group $(P<0.05)$. Feed intake at the 6th week of the $P 48$ group was high-

Table 2. Growth parameters of meagre fed with diets containing different protein ratios by cyclical feeding regimes for 6 weeks $(6 w)$ and 12 weeks $(12 w)$

\begin{tabular}{lccc}
\hline & P40/48 & P44/48 & P48 \\
\hline Initial mean weight $(\mathrm{g})$ & $49.59 \pm 0.60$ & $49.09 \pm 0.75$ & $50.22 \pm 0.22$ \\
Mean weight at 6w $(\mathrm{g})$ & $69.02 \pm 1.41^{\mathrm{ab}}$ & $65.15 \pm 1.26^{\mathrm{a}}$ & $74.04 \pm 1.83^{\mathrm{b}}$ \\
Mean weight at 12w $(\mathrm{g})$ & $86.04 \pm 0.87^{\mathrm{a}}$ & $82.77 \pm 2.28^{\mathrm{a}}$ & $94.25 \pm 1.71^{\mathrm{b}}$ \\
Feed intake at 6w $(\mathrm{g})$ & $73.64 \pm 0.16^{\mathrm{a}}$ & $75.79 \pm 0.84^{\mathrm{a}}$ & $83.37 \pm 4.23^{\mathrm{b}}$ \\
Feed intake at 12w (g) & $74.85 \pm 0.66^{\mathrm{a}}$ & $79.03 \pm 0.49^{\mathrm{a}}$ & $85.82 \pm 2.42^{\mathrm{b}}$ \\
Specific growth rate at 6w (\%/day) & $0.85 \pm 0.07$ & $0.73 \pm 0.02$ & $0.99 \pm 0.15$ \\
Specific growth rate at 12w (\%/day) & $0.71 \pm 0.03$ & $1.47 \pm 0.02$ & $0.81 \pm 0.08$ \\
Feed conversion ratio at 6w & $1.26 \pm 0.10$ & $1.50 \pm 0.06$ & $1.13 \pm 0.13$ \\
Feed conversion ratio at 12w & $1.32 \pm 0.04$ & $93.33 \pm 3.33$ & $1.26 \pm 0.08$ \\
Survival rate $\%$ ) & $96.67 \pm 3.33$ & $93.33 \pm 3.33$ \\
\hline In the same line, different letters indicate statistical significant differences $(\mathrm{P}<0.05)$ among the treatments &
\end{tabular}


er than both the $P 40 / 48$ and $P 44 / 48$ groups $(P<0.05)$. There were no statistical differences in the specific growth rates and feed conversion ratios at the $6^{\text {th }}$ week between the experimental groups $(P>0.05)$. The highest mean weight and feed intake values at the $12^{\text {th }}$ week were recorded in the $P 48$ group $(P<0.05)$. There were no statistical differences in the specific growth rates and feed conversion ratios at the $12^{\text {th }}$ week or in survival rates between all groups $(P>0.05)$.

In Figure 1, weight increments of the meagre are shown week by week. The very close mean weights were recorded in the 4th week in the P48 and P40/48 groups with 65.88 and 65.76 g, respectively. The mean weight of P40/48 dramatically deviated from the P48 after the 6th week. The mean weights in different weeks of P44/48 never reached that of either P48 or P40/48 groups during the study. The weight gains of experimental groups were noted as 44.02, 36.75, and 33.68 for P48, P40/48, and P44/48 groups, respectively (Figure 2).
The biological indices of the meagre fed with the different protein level diets are listed in Table 3. The condition factor (CF) of $P 48$ was significantly different to the $P 44 / 48(P<0.05)$. The highest viscerosomatic index (VSI) was found in the $P 40 / 48$ group $(P<0.05)$. No differences were observed in the hepatosomatic index (HSI) and mesenteric fat index (MFI) between the groups ( $P>0.05)$.

Economic analysis of this experiment is presented in Table 4. No significant difference was found in economic conversion ratios (ECR) across all groups ( $P>0.05)$. The economic profit index (EPI) of P48 was significantly different from $\mathrm{P} 44 / 48(\mathrm{P}<0.05)$.

The results of this present study clearly show that meagre need high protein levels in their diets and that decreasing the protein level (in their diets or partial feeding regimes) directly affects growth performance. In this study, cycled feeding with diets containing 40 and $44 \%$ protein levels were not as efficient as continuously feeding with $48 \%$ protein. Meagre is a fish species that

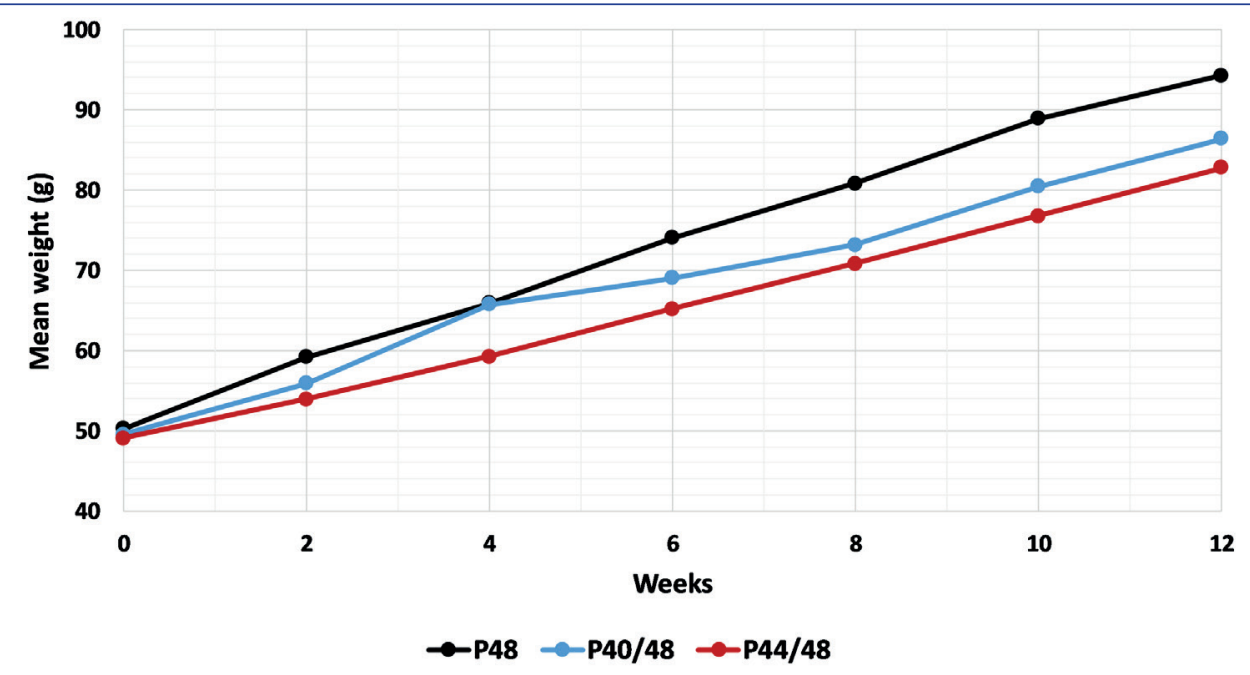

Figure 1. Mean weight increments of experimental groups of meagre during the 12 weeks.

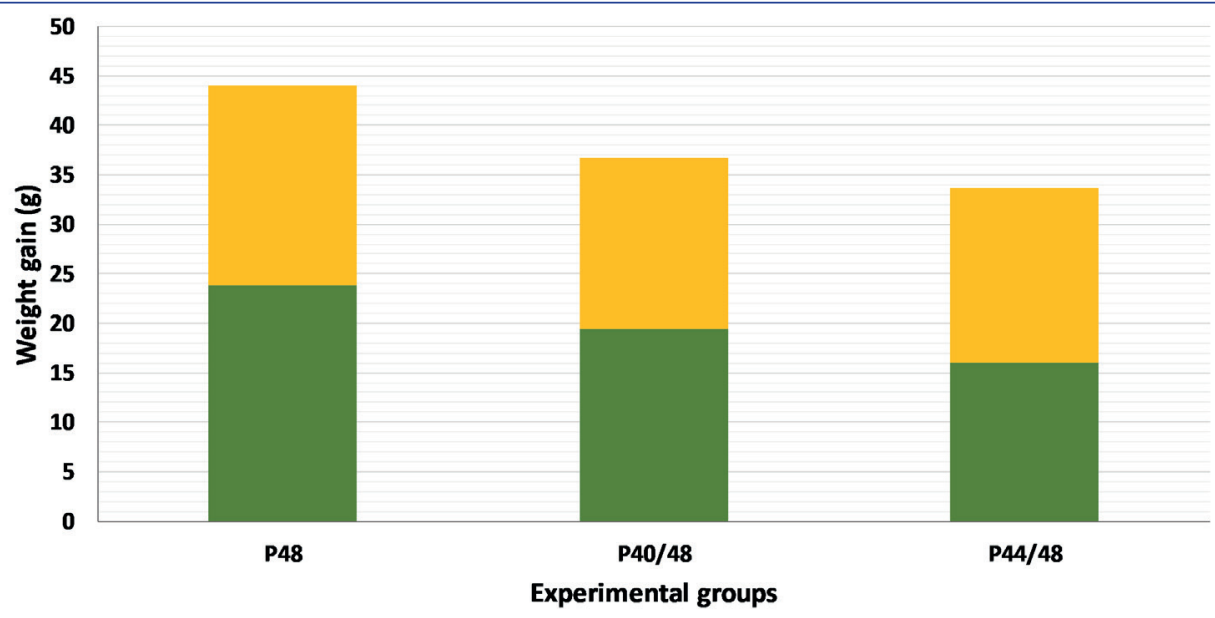

First 6 weeks Second 6 weeks

Figure 2. Weight gains of experimental groups of meagre during the 12 weeks. 
Table 3. Somatic indices of meagre fed with diets containing different protein ratios by cyclical feeding regimes for 84 days

\begin{tabular}{lccc}
\hline & $\mathbf{P 4 0 / 4 8}$ & $\mathbf{P 4 4 / 4 8}$ & $\mathbf{P 4 8}$ \\
\hline Condition factor (\%) & $1.37 \pm 0.01^{\mathrm{ab}}$ & $1.39 \pm 0.02^{\mathrm{b}}$ & $1.31 \pm 0.02^{\mathrm{a}}$ \\
Viscerosomatic index (\%) & $5.88 \pm 0.77^{\mathrm{b}}$ & $5.14 \pm 0.17^{\mathrm{a}}$ & $5.16 \pm 0.23^{\mathrm{a}}$ \\
Hepatosomatic index (\%) & $0.65 \pm 0.04$ & $0.69 \pm 0.03$ & $0.80 \pm 0.05$ \\
Mesenteric fat index (\%) & $0.04 \pm 0.01$ & $0.05 \pm 0.01$ & $0.08 \pm 0.02$ \\
\hline In the same line, different letters indicate statistical significant differences $(P<0.05)$ among the treatments &
\end{tabular}

Table 4. Profitability analysis of meagre fed with diets containing different protein ratios by cyclical feeding regimes

\begin{tabular}{lccc}
\hline & $\mathbf{P 4 0 / 4 8}$ & $\mathbf{P 4 4 / 4 8}$ & $\mathbf{P 4 8}$ \\
\hline Economic conversion ratio $(€ / \mathrm{kg})$ & $1.34 \pm 0.04$ & $1.58 \pm 0.07$ & $1.38 \pm 0.09$ \\
Economic profit index (€/fish) & $3.39 \pm 0.03^{\mathrm{ab}}$ & $3.19 \pm 0.10^{\mathrm{a}}$ & $\mathbf{3 . 6 4 \pm 0 . 0 8 ^ { \mathrm { b } }}$ \\
\hline In the same line, different letters indicate statistical significant differences $(\mathrm{P}<0.05)$ among the treatments & &
\end{tabular}

needs high dietary protein levels in the range of 45-50\% (Chatzifotis et al., 2012; Güroy et al., 2017).

The WG and FI of the P40/48 and P44/48 groups were found continuously lower than the P48 group during the experiment. Kureshy and Davis (2002) stated that protein requirement depends on the optimum protein ratio of the diet and inferior levels of protein might be recompensed by a higher feed intake. Nevertheless, in this study, dietary protein level and feed intake increased linearly. This could be explained by size of the fish. In previous studies carried out on several carnivorous marine fish, including yellowtail (Seriola dumerilii), Korean rockfish (Sebastes schlegeli), and parrotfish (Oplegnathus fasciatus) it was stated that $45-50 \%$ was the optimum protein ratio in the juvenile stages of these species (Jover et al., 1999; Cho et al., 2015; Kim et al., 2017). However, Craig and Helfrich (2017) declared that the protein requirements of fish were related to the life stages of the species. The authors also noted that older fish need lower levels of dietary protein. Interestingly, however, although there was a quantitative difference between the SGR and FCR parameters of the groups at the midpoint and at the end of the experiment, they were found to be significantly similar $(P>0.05)$. These parameters are used to specify the efficiency level of the feed or feeding regime in aquaculture (Craig and Helfrich, 2017). From this point of view, it is thought that the outputs of the study are useful for proving the importance of growth parameters in the condition of cyclical feeding regime with diets including different protein levels.

The CF displayed an inverse relation with the mean weights and feed intakes at the 6th and 12th weeks in this study. In contrast, Kim et al. (2001) recorded a parallel tendency between the CF and growth parameters in Korean rockfish (S. schlegeli). In a study carried out with grouper (Epinephelus coioides), the CF and VSI were improved at the optimum protein level (Luo et al., 2004). Yang et al. (2003) revealed that the VSI of Taiwan barb (Spinibarbus hollandi) was decreased with increased protein levels. The VSI was not enhanced with the highest growth (P48) in this current study. Kim et al. (2001) reported that the HSI of Korean rockfish (S. schlegeli) was improved with increased protein lev- els. Although there is no statistical difference between the groups, similar results were found in this present study (HSI ranged between 0.65 and 0.80 ). Lee et al. (1993) revealed that enhanced HSI was a sign of increased protein levels. An inverse record has been presented on the Atlantic cod (Gadus morhua) by Grisdale-Helland et al. (2008).

Fish meal and fish oil are the most expensive raw materials in aquafeeds. However, the carnivorous fish species need high quality animal protein sources in their diets. Decreasing the protein levels of diets means improving the profitability (Sweilum et al., 2005; Güroy et al., 2017). In this study, the EPI of P48 was higher than the other groups, but significantly related to P40/48. This situation might lead to a decrease in the production profitability in the culture of early stages of meagre, but this result may be useful for broodstock management because adult fish need less protein levels in their diets.

\section{CONCLUSION}

It can be concluded that meagre need high levels of protein in their diets and this species cannot compensate for reduced levels. Low levels of protein limited the growth performance and biological parameters of the fish. It is useful to compare the present study with previous protein level studies because this particular type of study has not been examined before. As mentioned above, the outputs of this study may be beneficial in adult feeding or broodstock management in the meagre culture and for future studies related to cyclical feeding regimes with important nutrients in the diets.

Conflicts of interest: The authors have no conflicts of interest to declare.

Ethics committee approval: This study was carried out in accordance with animal welfare and the ethics of experimentation.

Acknowledgements: Some parts of this study were presented in the $18^{\text {th }}$ National Fisheries Symposium, Izmir, Turkey as a poster presentation on September 1-4 ${ }^{\text {th }}, 2015$. 


\section{REFERENCES}

Barata, M., Soares, F., Aragão, C., Almeida, A.C., Pousão-Ferreira, P. \& Ribeiro, L. (2016). Efficiency of 2-phenoxyethanol and clove oil for reducing handling stress in reared meagre, Argyrosomus regius (Pisces: Sciaenidae). Journal of the World Aquaculture Society, 47(1), 82-92. [CrossRef]

Chatzifotis, S., Panagiotidou, M. \& Divanach, P. (2012). Effect of protein and lipid dietary levels on the growth of juvenile meagre (Argyrosomus regius). Aquaculture International, 20(1), 91-98. [CrossRef]

Cho, S. H., Kim, H. S., Myung, S. H., Jung, W. G., Choi, J. \& Lee, S. M. (2015). Optimum dietary protein and lipid levels for juvenile rockfish (Sebastes schlegeli, Hilgendorf 1880). Aquaculture Research, 46(12), 2954-2961. [CrossRef]

Craig, S. \& Helfrich, L. (2017). Understanding fish nutrition, feeds, and feeding. Virginia Cooperative Extension, Publication 420-256. College of Agriculture and Life Sciences, Virginia Tech, Blacksburg, $6 \mathrm{p}$.

Emre, Y., Kurtoğlu, A., Emre, N., Güroy, B. \& Güroy, D. (2016). Effect of replacing dietary fish oil with soybean oil on growth performance, fatty acid composition and haematological parameters of juvenile meagre, Argyrosomus regius. Aquaculture Research, 47(7), 22562265. [CrossRef]

Eroldoğan, O. T., Taşbozan, O. \& Tabakoğlu, S. (2008). Effects of restricted feeding regimes on growth and feed utilization of juvenile gilthead sea bream, Sparus aurata. Journal of the World Aquaculture Society, 39(2), 267-274. [CrossRef]

Gatlin III, D. M., Barrows, F. T., Brown, P., Dabrowski, K., Gaylord, T. G., Hardy, R. W., Herman, E., Hu, G., Krogdahl, Å., Nelson, R., Overturf, K., Rust, M., Sealey, W., Skonberg, D., Souza, E. J., Stone, D., Wilson, R. \& Wurtele, E. (2007). Expanding the utilization of sustainable plant products in aquafeeds: A review. Aquaculture Research, 38(6), $551-$ 579. [CrossRef]

Gaylord, T. G. \& Gatlin III, D. M. (2001). Dietary protein and energy modifications to maximize compensatory growth of channel catfish (Ictalurus punctatus). Aquaculture, 194, 337-348. [CrossRef]

Grisdale-Helland, B., Shearer, K. D., Gatlin III, D. M. \& Helland, S. J. (2008). Effects of dietary protein and lipid levels on growth, protein digestibility, feed utilization and body composition of Atlantic cod (Gadus morhua). Aquaculture, 283(1-4), 156-162. [CrossRef]

Güroy, D., Karadal, O., Güroy, B., Mantoğlu, S., Çelebi, K., Şimşek, O., Eroldoğan, O. T., Genç, M. A. \& Genç, E. (2017). The effects of dietary protein levels with amino acid supplementation on the growth performance, haematological profile and histology of meagre (Argyrosomus regius) in two different size classes. Aquaculture Research, 48(12), 5751-5764. [CrossRef]

Hartviksen, M., Bakke, A. M., Vecino, J. G., Ringø, E. \& Krogdahl, Å. (2014). Evaluation of the effect of commercially available plant and animal protein sources in diets for Atlantic salmon (Salmo salar L.): digestive and metabolic investigations. Fish Physiology and Biochemistry, 40(5), 1621-1637. [CrossRef]

IndexMundi. (2018). IndexMundi - Country Facts, <www.indexmundi. com/commodities> (Accessed Date: 05.08.2018).

Jiwyam, W. (2010). Growth and compensatory growth of juvenile Pangasius bocourti Sauvage, 1880 relative to ration. Aquaculture, 306, 393-397. [CrossRef]

Jover, M., Garcia-Gómez, A., Tomas, A., de la Gándara, F. \& Pérez, L. (1999). Growth of Mediterranean yellowtail (Seriola dumerilii) fed extruded diets containing different levels of protein and lipid. Aquaculture, 179(1-4), 25-33. [CrossRef]
Kim, K. W., Kim, K. D., Han, H. S., Moniruzzaman, M., Yun, H., Lee, S. \& Bai, S. C. (2017). Optimum dietary protein level and protein-toenergy ratio for growth of juvenile parrot fish, Oplegnathus fasciatus. Journal of the World Aquaculture Society, 48(3), 467-477. [CrossRef]

Kim, K. W., Wang, X. J. \& Bai, S. C. (2001). Reevaluation of the optimum dietary protein level for the maximum growth of juvenile Korean rockfish, Sebastes schlegeli (Hilgendorf). Aquaculture Research, 32(1), 119-125. [CrossRef]

Kureshy, N. \& Davis, D. A. (2002). Protein requirement for maintenance and maximum weight gain for the Pacific white shrimp, Litopenaeus vannamei. Aquaculture, 204(1-2), 125-143. [CrossRef]

Lee J. Y., Kang Y. J., Lee S. M. \& Kim I. B. (1993). Protein requirements of the Korean rockfish Sebastes schlegeli. Journal of Aquaculture, 6(1): 13-27.

Lovell, T. (1989). Nutrition and Feeding of Fish. Van Nostrand Reinhold, New York. [CrossRef]

Luo, Z., Liu, Y. J., Mai, K. S., Tian, L. X., Liu, D. H. \& Tan, X. Y. (2004). Optimal dietary protein requirement of grouper Epinephelus coioides juveniles fed isoenergetic diets in floating net cages. Aquaculture Nutrition, 10(4), 247-252. [CrossRef]

Monfort, M. (2010). Present market situation and prospects of meagre (Argyrosomus regius), as an emerging species in Mediterranean aquaculture. In Studies and Reviews. General Fisheries Commission for the Mediterranean. FAO, Rome, Italy.

NRC. (2011). Nutrient requirements of fish and shrimp. National Research Council (NRC), National Academies Press.

Quinton, J. C. \& Blake, R. W. (1990). The effect of feed cycling and ration level on the compensatory growth response in rainbow trout, Oncorhynchus mykiss. Journal of Fish Biology, 37(1), 33-41. [CrossRef]

Ribeiro, L., Soares, F., Quental-Ferreira, H., Gonçalves, A. \& PousãoFerreira, P. (2013). Portuguese research studies meagre production in earthen ponds. Global Aquaculture Advocate, 16, 38-40.

Okorie, O. E., Bae, J. Y., Kim, K. W., Son, M. H., Kim, J. W. \& Bai, S. C. (2013). Optimum feeding rates in juvenile olive flounder, Paralichthys olivaceus, at the optimum rearing temperature. Aquaculture Nutrition, 19(3), 267-277. [CrossRef]

Sánchez-Lozano, N. B., Vidal, A. T., Martínez-Llorens, S., Mérida, S. N., Blanco, J. E., López, A. M., Torres, M. P. \& Cerdá, M. J. (2007). Growth and economic profit of gilthead sea bream (Sparus aurata, L.) fed sunflower meal. Aquaculture, 272(1-4), 528-534. [CrossRef]

Sweilum, M. A., Abdella, M. M. \& Salah El-Din, S. A. (2005). Effect of dietary protein-energy levels and fish initial sizes on growth rate, development and production of Nile tilapia, Oreochromis niloticus L. Aquaculture Research, 36(14), 1414-1421. [CrossRef]

Tacon, A. G. \& Cowey, C. B. (1985). Protein and aminoacids requirements. In P. Tytler \& P. Calow (Eds.), Fish energetics, new perspectives (pp. 155-183). Croom Helm, London and Sydney. [CrossRef]

Türkmen, S., Eroldoğan, O. T., Yılmaz, H. A., Ölçülü, A., Kiriş İnan, G. A., Erçen, Z. \& Tekelioğlu, N. (2012). Compensatory growth response of European sea bass (Dicentrarchus labrax L.) under cycled starvation and restricted feeding rate. Aquaculture Research, 43(11), 1643-1650. [CrossRef]

Vallés, R. \& Estévez, A. (2013). Light conditions for larval rearing of meagre (Argyrosomus regius). Aquaculture, 376-379: 15-19. [CrossRef]

Yang, S. D., Lin, T. S., Liou, C. H. \& Peng, H. K. (2003). Influence of dietary protein levels on growth performance, carcass composition and liver lipid classes of juvenile Spinibarbus hollandi (Oshima). Aquaculture Research, 34(8): 661-666. [CrossRef]

Zar, J. H. (1999). Biostatistical analysis. 4th edt, Upper Saddle River: Prentice-Hall Inc. 929 p. 